Iskra Ryslana, Slivinska Oksana, Shatynska Olena, Svarchevska Oksana, Senkiv Oksana, Pulipez Andriy. Metabolic Processes in rats' Liver Under the Condition of Experimental Diabetes and Chromium Citrate Influence. Under the condition of diabetes mellitus an energetic exhaustion of organism is observed, which leads to the deficiency of energetic substrates and it affects the effectiveness of antioxidant system functioning in direct proportion. Under the condition of experimental diabetes credible increase of MDA content, decrease of catalase, glutathione peroxidase, lactate dehydrogenase activities and the content of reduced glutathione were established in liver tissue of rats. After the addition of chromium citrate in a quantity of 10 and $25 \mathrm{mcg} \mathrm{Cr}_{3}{ }^{+} / \mathrm{kg}$ body weight to the diet of rats those researched indexes reach to their levels in the control group, while activities of lactate dehydrogenase, glucose-6-phosphate dehydrogenase, catalase, glutathione peroxidase and the content of the reduced glutathione increase compared to rats with experimental diabetes, although the content of lipid peroxidation products decrease.

Key words: rats, chromium citrate, experimental diabetes, liver.

Стаття надійшла до редколегії 28.01.2015 p.

УДК 612.172-055.25

\author{
Тетяна Качинська, \\ Ольга Абрамчук, \\ Оксана Поліщук, \\ Юлія Шершень
}

\title{
Особливості часових показників варіативності серцевого ритму в дівчат різного шкільного віку під час виконання когнітивних завдань
}

Вивчено часові показники ВСР у дівчат різного шкільного віку під час розумового навантаження. В осіб середнього шкільного віку виконання когнітивних завдань супроводжувалося більшим психоемоційним напруженням організму, компенсованим дисстресом та переважанням симпатичного рівня регуляції в серцевій діяльності.

Ключові слова: варіативність серцевого ритму, дисстрес, ваготонія, симпатикотонія.

Постановка наукової проблеми та ії значення. Для сучасного етапу розвитку суспільства характерне збільшення потоку інформації, що є причиною зростання психоемоційного напруження та загального рівня гіпокінезії тощо [7, с. 73-76]. Численні дослідження свідчать, що умови антропогенного навантаження приводять до більш інтенсивного використання адаптаційних можливостей організму. Відомо, що здоров’ я людини характеризується не лише відсутністю патологічно змінених органів і систем, але й функціональними резервами, які забезпечують ефективну адаптацію до мінливих умов середовища. Установлено, що функціональні резерви організму людини значною мірою визначаються резервами регуляції [1, с. 473-496].

Аналіз досліджень цієї проблеми. Варіабельність серцевого ритму (ВСР) - універсальна фізіологічна властивість, яка не лише відображає стан вегетативної нервової системи, але і $є$ показником регуляторних процесів на рівні цілісного організму [1, с. 473-496], відображає стан його адаптаційних резервів та резервів здоров’я. ВСР дає змогу виявити особливості регуляторних механізмів серця під час фізичних навантажень в осіб із різними типами гемодинаміки, є чутливим показником оцінки ризику розвитку захворювань [6, с. 66-72], свідчить про рівень аеробного метаболізму [5, с. 48-67], пов’ язана 3 максимальною аеробною потужністю й складом тіла [10, с. 2304-2310]. Утановлено: ВСР знижується 3 появою надлишкової маси та розвитком ожиріння в дітей [9], а також відображає особливості статевого розвитку й перебігу фаз менструального циклу [3, с. 300-305].

Організм підлітків через незавершеність морфофункціонального розвитку [11, с. 269-273], недосконалість його регуляторних механізмів, високу лабільність гостро реагує на впливи несприятливих факторів [2, с. 18-24]. У науковій літературі визнано, що соматотип є морфогенетичним маркером, який регламентує особливості розвитку організму на різних етапах онтогенезу. Проте перебіг процесів регуляції в період росту й розвитку організму, залежно від інтенсивності когнітивного навантаження, у науковій літературі розкрито недостатньо. Тому мета роботи полягала у

(ㄷ Качинська Т., Абрамчук О., Поліщук О., Шершень Ю., 2015 
вивченні вікових особливостей часових показників варіативності серцевого ритму в дівчат середнього та старшого шкільного віку під час виконання розумових завдань.

Матеріали та методи дослідження. У дослідженні брали участь 40 дівчат віком 12-13 та 15-17 років, учнів НВК № 9 м. Луцька. Усі вони були здоровими, згідно 3 даними соматичного й психоневрологічного обстеження. Дослідження проводили з урахуванням фаз менструального циклу. Усіх обстежуваних поділено на дві основні групи: I - дівчата середнього шкільного віку - підлітки (20 осіб); II - дівчата старшого шкільного віку - старшокласниці (20 осіб).

Вивчення особливостей ВСР здійснювали в лабораторії «вікової нейрофізіології» кафедри фізіології людини і тварин. Перед початком запису варіабельності серцевого ритму визначали артеріальний тиск та частоту серцевих скорочень досліджуваних. Вивчення особливостей варіативності серцевого ритму в дівчат різного шкільного віку під час розумових навантажень здійснювали за допомогою комп'ютерного кардіографічного комплексу «КардіоЛаб», розробленого науково-технічним центром XАI-МЕДИКА (м. Харків). Запис ЕКГ здійснювали в стандартних відведеннях (ліва рука - ліва нога, права рука - права нога) [1, с. 473-496].

Тривалість реєстрації кардіоінтервалограми становила не менше 300 мс. У подальшому розраховували часові стандартизовані характеристики динамічного ряду кардіоінтервалів: $\mathrm{mRR}$ (мc), Mо, AMo, pNN50, ИН(SI), CV, SDNN [1, c. 473-496].

Запис ВСР виконували під час таких експериментальних ситуацій: дій);

1) фонова проба (досліджувані перебували в стані спокійного неспання та не виконували ніяких

2) запис ВСР під час виконання когнітивного завдання (розв'язування математичних прикладів, підібраних відповідно до навчальної програми учнів, під час усього часу запису проби). У кінці виконання завдання досліджувані повідомляли про кількість прикладів, які їм удалося розв' язати, та повідомляли результат. Отже, створювалася мотивація до виконання завдання й здійснювалася його перевірка.

Статистичну обробку проводили, використовуючи програму MS Excel 2010. Визначали нормальність розподілу даних. Для парного порівняння груп використовували критерії достовірності Стьюдента (t) та Мана-Уітні (W). Різницю між двома середніми величинами вважали достовірною при значеннях $\mathrm{t} \geq 2,0$ і $\mathrm{p} \leq 0,05$. Визначали середнє значення показника $(\mathrm{M})$, величину середньої похибки $( \pm \mathrm{m})[4]$.

Виклад основного матеріалу й обгрунтування отриманих результатів дослідження. Аналіз результатів дослідження в дівчат-підлітків і старшокласників засвідчив, що під час виконання розумового навантаження, порівняно з фоном, простежується зміна показників ВСР. Так, показник $\mathrm{mRR}$ у дівчат-підлітків у стані спокою становив $644 \pm 23,77$ мс, під час розв'язання арифметичних завдань його величина зменшилася, порівняно з фоном, на 67 мс $(577 \pm 14,1$ мс). Статистично достовірно вищі значення показника були під час запису фонової проби, порівняно з 2-ю експериментальною ситуацією $(\mathrm{p} \leq 0,05)$ (рис. 1$)$.

Подібну тенденцію простежено і в осіб старшого шкільного віку. Зафіксовано скорочення серцевого циклу на 114 мс, що вказує на прискорення роботи серця в процесі реалізації розумового навантаження. Статистично достовірно вищі значення показника були під час запису фонової проби, порівняно з 2-ю експериментальною ситуацією $(\mathrm{p} \leq 0,05)$ (рис. 1). Отже, під час виконання розумових вправ, незалежно від віку досліджуваних, відзначено зменшення показника $\mathrm{mRR}$, що вказує на прискорення роботи серцевого м'яза та перевагу симпатичної регуляції в процесі розв'язання інтелектуальних завдань.

Часовий показник SDNN у дівчат-підлітків характеризувався вищими його значеннями під час запису фонової проби, порівняно з 2-ю експериментальною ситуацією (рис. 1). Так, значення досліджуваного показника в 1-й експериментальній ситуації становило $53 \pm 4,21$ мс, у 2-й $-47 \pm 4,4$ мс. Статистично достовірної різниці між показниками не виявлено. В осіб старшого шкільного віку вищі значення ними зафіксовано під час запису фонової проби, порівняно з розумовим навантаженням (рис. 1). Статистично достовірно вищі його значення відзначено під час 1-ї експериментальної ситуації, порівняно з 2-ю ( $\leq \leq 0,05)$. 

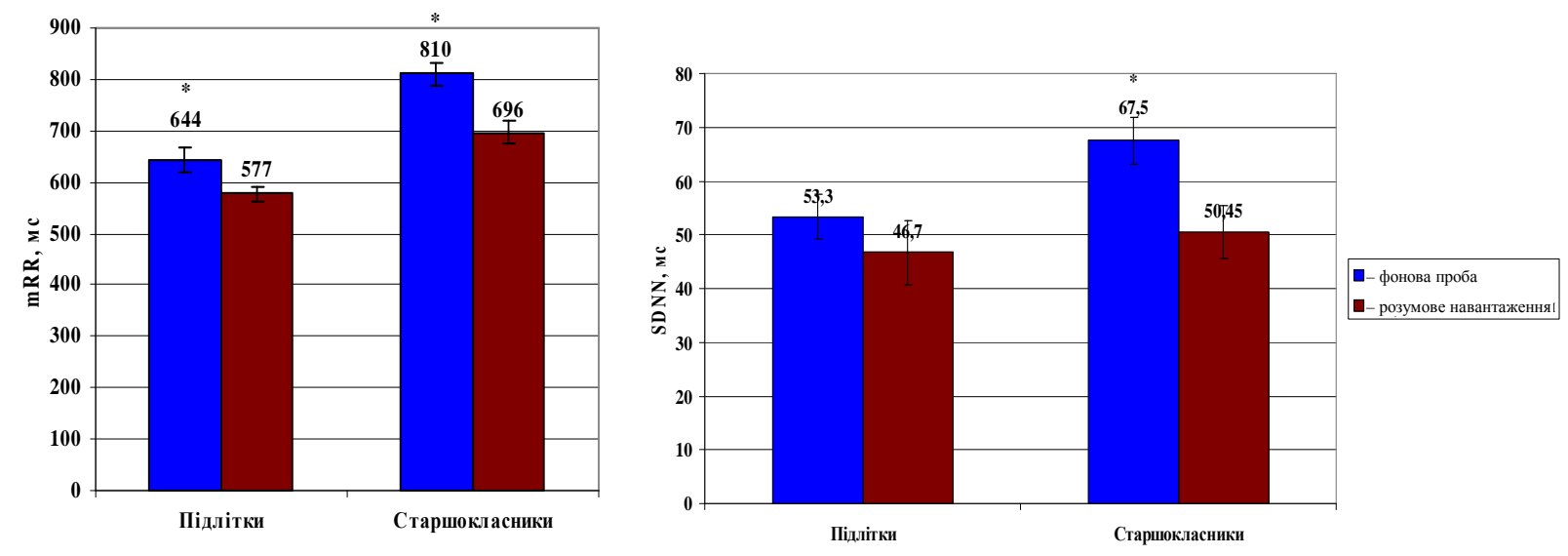

Рис. 1. Показники mRR та SDNN варіативності сериевого ритму в дівчат-підлітків та старшокласниць під час різних експериментальних ситуаџій

* - статистично достовірно вищі показники $(\mathrm{p} \leq 0,05)$.

CV - коефіцієнт варіації являє собою нормовану оцінку дисперсії (D) і може порівнюватися в осіб із різними значеннями частоти пульсу. У дівчат середнього шкільного віку в стані спокою значення CV -

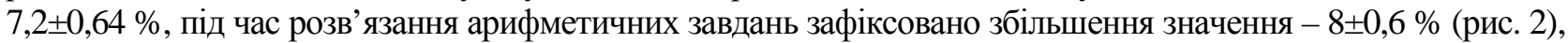
тоді як в осіб старшого шкільного віку - зворотна динаміка (зменшення значень досліджуваного показника під час розумового навантаження, порівняно 3 фоновою пробою) (рис. 2). Отже, в осіб середнього шкільного віку під час розв’язання арифметичних завдань простежено напруження регуляції роботи серця та збільшення ступеня його реактивності. В осіб старшого шкільного віку зменшення CV під час розумового навантаження вказує на більш виражений парасимпатичний тонус на роботу серця.
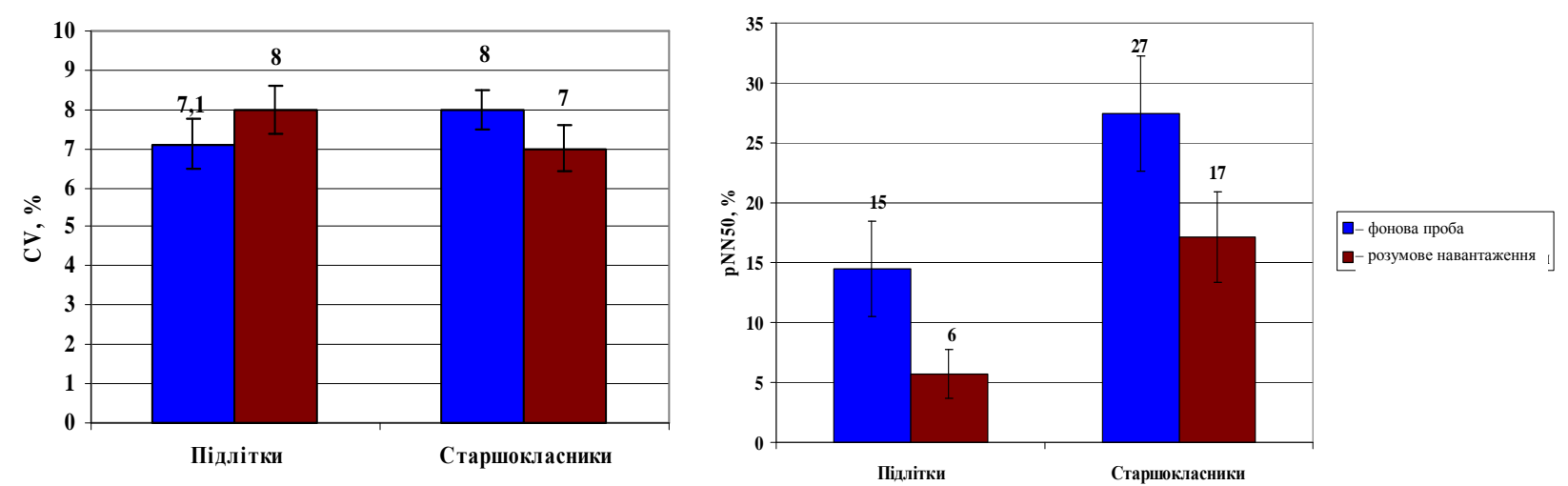

Рис. 2. Показники CV, pNN50 варіативності серцевого ритму в дівчат-підлітків та старшокласниць під час різних експериментальних ситуацій

Показники pNN50 під час запису фонової проби в дівчат середнього та старшого шкільного віку характеризувалися вищими значеннями, порівняно 3 2-ю експериментальною ситуацією. Під час 1-ї

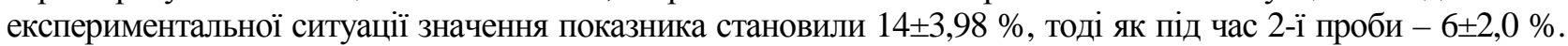
(рис. 2). Уявлення про регуляторно-адаптативний статус указує, що чим вище визначення pNN50, тим активнішою є ланка парасимпатичної регуляції та меншим ступінь напруження регуляторних систем. Результати наших досліджень свідчать, що, незалежно від вікової групи, під час розв’ язання арифметичних завдань підвищується ступінь напруження регуляторних систем та більшою мірою, особливо в підлітків, проявляє свою активність симпатична ланка в регуляції серцевої діяльності.

Показник Мо під час запису фонової проби в дівчат середнього шкільного віку характеризувався вищими значеннями, порівняно 3 2-ю експериментальною ситуацією. Статистично достовірно вищі значення показника зафіксовано під час запису фонової проби, порівняно з розумовим навантаженням $(\mathrm{p} \leq 0,05)$ 
(рис. 3). В осіб старшого шкільного віку вищі значення цього показника виявлено під час запису фонової проби, порівняно з розумовим навантаженням (фон. проба $-800 \pm 26,3$ мс / розум. навант. $-658 \pm 22,1$ мс, $\mathrm{p} \leq 0,05)$. Зменшення значень Мо під час розумового навантаження, незалежно від вікової групи, указує на переважання тонусу симпатичної нервової системи (симпатикотонії) в процесі реалізації когнітивного завдання.
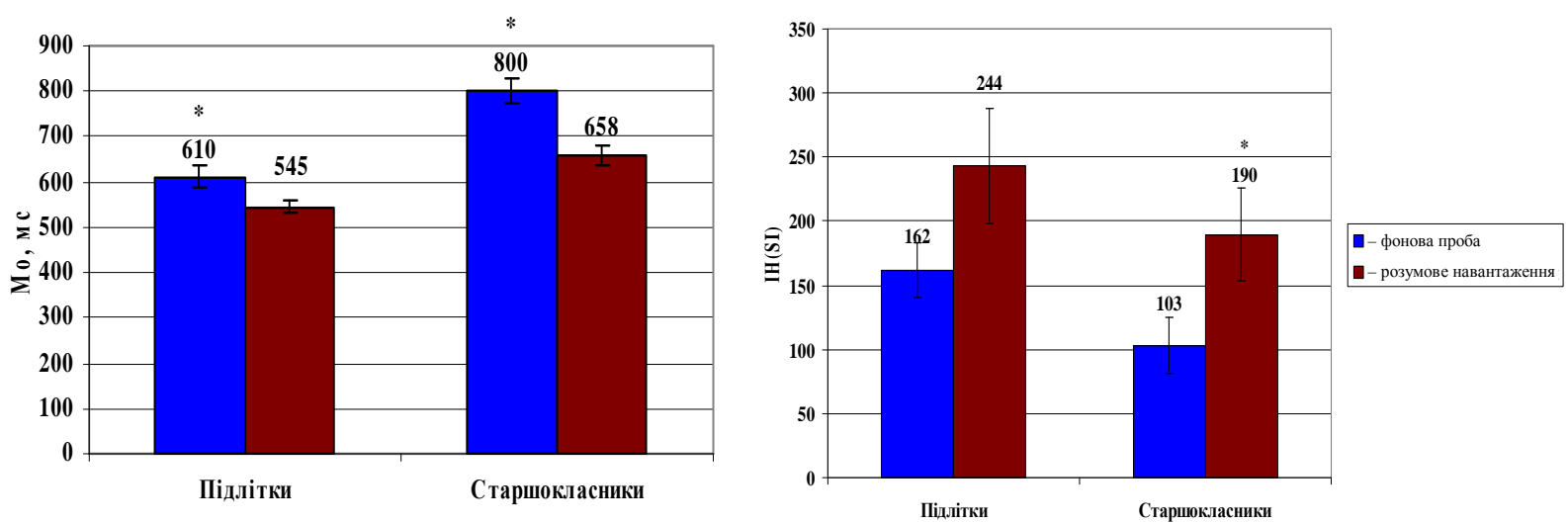

Рис. 3. Показники Мо, IH(SI) варіативності серцевого ритму в дівчат підлітків та старшокласниць під час різних експериментальних ситуацій

* - статистично достовірно вищі показники $(\mathrm{p} \leq 0,05)$

Показник АМо в дівчат середнього шкільного віку під час запису II експериментальної ситуації, порівняно з фоновою пробою, характеризувався поступовим збільшенням значень від 40 $\pm 2,48$ \% (фонова проба) до 41,0 33,7 \% (розумове навантаження). У дівчат старшого шкільного віку найвище значення АМо зафіксовано під час запису ВСР у процесі виконання розумового навантаження $(42 \pm 3,1 \%)$, тоді як під час

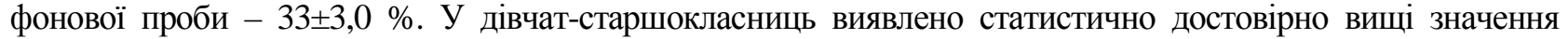
досліджуваного показника під час 2-ї експериментальної ситуації, порівняно з 1-ю (p $\leq 0,05)$.

Під час запису ВРС у стані спокою вищі значення IH(SI) зафіксовано в процесі розв'язування арифметичних завдань, порівняно із записом фонової проби (фон. проба - $161 \pm 21,8$ / розум. навант. $-244 \pm 44,7)$. Проте статистично достовірної різниці не виявлено (рис. 3). В осіб старшого шкільного віку індекс напруження характеризувався вищими значеннями під час реалізації когнітивного завдання, порівняно із фоновим записом ВСР (фон. проба - 103 $\pm 21,8$ / розум. навант. - 190 $\pm 36,2$ ). Статистично достовірно вищі значення відзначено під час розумового навантаження, порівняно з фоном (p $\leq 0,05)$ (рис. 3 ).

Досліджуючи показник $\mathrm{mRR}$, виявили його зміни в процесі росту та розвитку організму школярок. Так, під час запису фонової проби в дівчат-старшокласниць зафіксовано статистично достовірно вищі значення mRR, порівняно з підлітками (підлітки - 644 $\pm 23,77$ мс /старшокласниці - 810 $\pm 23,3, \mathrm{p} \leq 0,05$ ). Під час розв'язання арифметичних завдань виявлено подібну динаміку, достовірно вищі значення досліджуваного показника в дівчат-старшокласниць.

Вивчення особливостей показника SDNN у процесі онтогенезу за різних експериментальних ситуацій показало вищі його значення в осіб старшої шкільної групи, порівняно з підлітками.

Часовий показник pNN50 теж характеризувався збільшенням його значень у процесі онтогенезу. Так, під час запису ВСР у стані спокою та в процесі розв'язання арифметичних завдань вищі його значення були в дівчат старшого шкільного віку, порівняно з підлітками.

Показник Мо характеризувався статистично достовірно вищими значеннями в осіб старшого шкільного віку, порівняно з дівчатами-підлітками, незалежно від тестової ситуації. Дані Мо, що вказують на домінуючий рівень функціонування синусового вузла, характеризувалися вищими значеннями в дівчатстаршокласниць, що свідчить про ваготонію в цій групі досліджуваних, тоді як для підлітків більш характерна симпатикотонія незалежно від тестової ситуації.

Дослідження АМо в процесі онтогенезу показало вищі значення в осіб середнього шкільного віку, порівняно зі старшокласницями, під час запису фонової проби. У процесі розв'язування арифметичних прикладів зафіксовано зворотну динаміку. АМо, що вказує на міру мобілізаційного впливу симпатичного відділу нервової системи, під час фонового запису ВСР характеризувалася вищими впливами симпатичної 
нервової системи на серцеву діяльність у дівчат-підлітків, тоді як під час розумового навантаження високий вплив від СНС зафіксовано в обох групах.

$\mathrm{IH}$ - індекс напруження регуляторних систем (він же - SI - stress index) характеризувався зниженням його значень у процесі онтогенезу. Під час запису фонової проби значення IН були достовірно вищі в дівчатпідлітків, порівняно зі старшокласницями (підлітки - 161 $\pm 21,8$ /старшокласниці $-103 \pm 21,8, \mathrm{p} \leq 0,05)$. У процесі розв'язування арифметичних прикладів вищі значення показника зафіксовано теж в осіб середнього

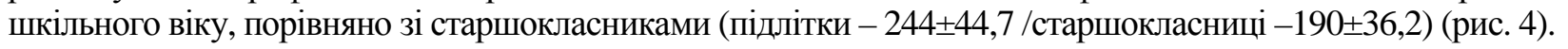

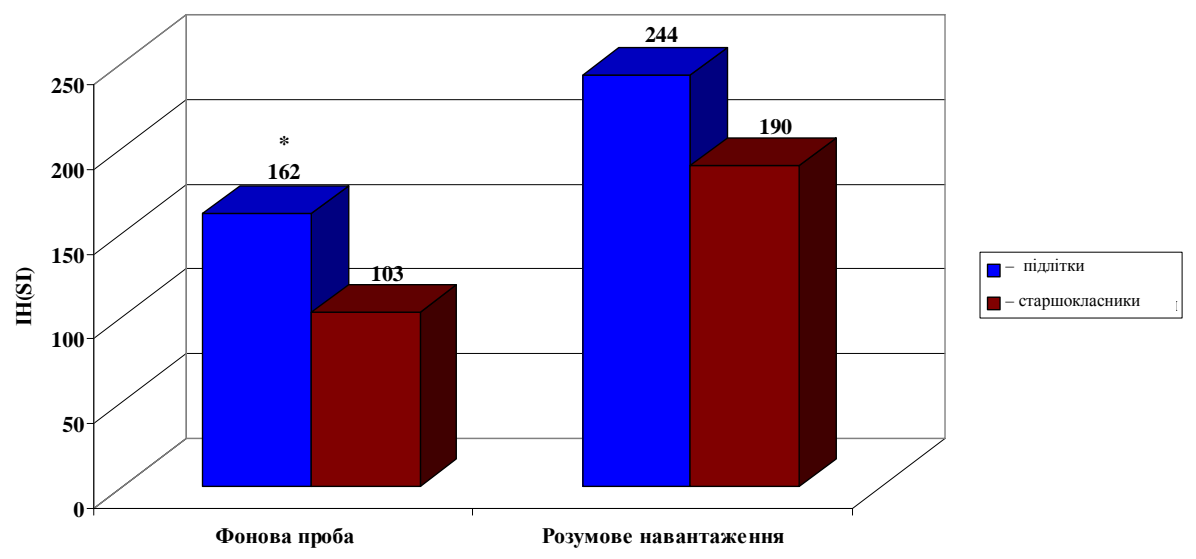

Рис. 4. Показники IH(SI) варіативності сериевого ритму під час різних експериментальних ситуацій залежно від віку

* - статистично достовірно вищі показники IH(SI) $(\mathrm{p} \leq 0,05)$.

Отже, ураховуючи вік досліджуваних, часові показники mRR, SDNN, pNN50, CV, Mo, AMо характеризувалися вищими значеннями в дівчат-старшокласниць, а IH(SI) - у дівчат середнього шкільного віку.

Аналіз даних варіативності серцевого ритму залежно від тестової ситуації засвідчив, що часові характеристики $\mathrm{mRR}, \mathrm{SDNN}, \mathrm{pNN} 50, \mathrm{CV}$, Мо під час виконання розумових навантажень, порівняно із фоном, мають нижчі значення, тоді як $\mathrm{AMo,} \mathrm{IH}(\mathrm{SI})$ характеризувалися збільшенням їхніх значень під час розв'язання арифметичних прикладів, порівняно з фоновим записом ВСР.

Згідно з класичною інтерпретацією, під час стандартної реєстрації 5-хвилинних відрізків серцевого ритму збільшення показників часового аналізу ВСР відбувається за посилення парасимпатичних впливів та зниження - під час активації симпатичного тонусу [1, с. 473-496]. Так, у дівчат-старшокласниць значення часових показників mRR, SDNN, pNN50, CV, Mo, AMо були вищими, порівняно з підлітками, що вказує на більший рівень парасимпатичної регуляції роботи серця в дівчат старшого шкільного віку. В осіб середнього шкільного віку виявлено вищі значення часових даних $\mathrm{AMo}$ та $\mathrm{IH}(\mathrm{SI})$ указують на більше психоемоційне напруження організму незалежно від функціонального стану, а значення IH від 161 до 244 - на компенсований дисстрес. Часовий аналіз ВСР у дівчат-підлітків засвідчив нормальність функціонування серцево-судинної системи досліджуваних, незалежно від тестової ситуації за показниками SDNN (40-80 мс), pNN50 (16-26 \%) [8], проте IH(SI) характеризувався нормою лише в осіб старшого шкільного віку під час запису фонової проби ВСР, тоді як у підлітковому віці, незалежно від тестової ситуації, значення стресіндексу вказують на компенсований дисстрес. Досліджувані показники свідчать, що, незалежно від віку досліджуваних та тестової ситуації, дівчата-школярки характеризуються високими рівнем мобілізаційного та відновного потенціалу.

Висновки та перспективи подальшого дослідження. Часові показники $\mathrm{mRR}, \mathrm{SDNN}, \mathrm{pNN} 50, \mathrm{CV}$, Mo, АМо характеризувалися вищими значеннями в дівчат-старшокласниць, порівняно $з$ досліджуваними середнього шкільного віку, а IH(SI) - у дівчат середнього шкільного віку, порівняно зі старшокласницями.

Для часових характеристик $\mathrm{mRR}, \mathrm{SDNN}, \mathrm{pNN} 50, \mathrm{CV}$, Мо під час виконання розумових навантажень, порівняно із фоном, властиві нижчі значеннями, незалежно від віку досліджуваних. AMo, IH(SI) характеризувалися збільшенням значень під час розв'язання арифметичних прикладів, порівняно з фоновим записом BCP.

В осіб середнього шкільного віку виконання когнітивних завдань супроводжувалося більшим психоемоційним напруженням організму, компенсованим дисстресом та переважанням симпатичного рівня регуляції в серцевій діяльності. 
У подальшому планується вивчення частотних показників ВСР у дівчат різного шкільного віку під час виконання арифметичних завдань.

\section{Джерела та література}

1. Баевский Р. М. Вариабельность сердечного ритма: теоретические аспекты и возможности клинического применения / Р. М. Баевский, С. В. Грачева, Г. Г. Иванова // Новые методы электрокардиографии. - 2007. - № 7. - С. 473-496.

2. Белова О. А. Диагностика вегетативных функций у подростков общеобразовательных школ и использование здоровьеориентированных технологий с целью оптимизации здоровья (1999-2009) / О. А. Белова // Фундаментальные исследования. - 2010. - № 3. - С. 18-24.

3. Димитриев Д. А. Особенности функционирования сердечно-сосудистой системы в разные фазы менструального цикла / Д. А. Димитриев, А. Д. Димитриев, Ю. Д. Карпенко // Рос. физиол. журн. - 2007. № 3. - С. 300-305.

4. Елисеева И. И. Общая теория статистики / И. И. Елисеева. - М. : Финансы и статистика, 2004. - 656 с.

5. Єлісєєва О. П. Дослідження механізмів взаємозв'язків аеробного метаболізму та ВСР у пацієнтів різних функціональних груп: коригуючий ефект олії амаранта. - Ч. 1 / О. П. Єлісєєва, Х. О. Семен, Д. В. Камінський // Експеримент. і клін. фізіологія та біохімія. - 2011. - № 2. - С. 48-67.

6. Коритко 3. І. Особливості регуляторних механізмів серця у формуванні перехідних адаптаційно-компенсаторних станів за умов граничних фізичних навантажень / 3. І. Коритко // Експеримент. і клін. фізіологія та біохімія. - 2011. - № 3. - С. 66-72.

7. Попов О. І. Психолого-гігієнічна сутність, види та особливості здоров'язберігаючих технологій у дітей в умовах сучасного навколишнього середовища / О. І. Попов, С. Є. Лупаренко, Л. Т. Бойко // Довкілля та здоров'я. - 2011. - № 3. - С. 73-76.

8. Яблучанский Н. И. Вариабельность сердечного ритма в помощь практическому врачу / Н. И. Яблучанский, А. В. Мартыненко. - Харьков : Для настоящих врачей, 2010. - 131 с.

9. Birch S. L. Overweight and reduced heart rate variability in Brit-ish children: An exploratory study / S. L. Birch, M. J. Duncan, C. Franklin // Prev. Med. - 2012. - Sep. 23. pil: S0091-7435(12) 00462-8.

10. Esco M. R. Skinfold thickness is related to cardiovascular auto-nomic control as assessed by heart rate variability and heart rate recovery / M. R. Esco, H. N. Williford, M. S. Olson // J. Strength Cond Res. - 2011. - № 25. - V. 8. P. 2304-2310.

11. Fukuba Y. Autonomic nervous activities assessed by heart rate variability in pre- and post-adolescent Japanese / Y. Fukuba, H. Sato, T. Sakiyama // J. Phisiol. Antropol. -2009. - Nov. 28. - V. 6. - P. $269-273$.

Качинская Татьяна, Абрамчук Ольга, Полищук Оксана, Шершень Юлия. Особенности временных показателей вариативности сердечного ритма у девочек разного школьного возраста во время решения когнитивных заданий. Цель работы изучение временных показателей вариативности сердечного ритма у девочек среднего и старшего школьного возраста во время решения когнитивных заданий. Исследуются 40 лиц женского пола в возрасте 12-13 и 15-17 лет, разделенные на группы: I - девушки среднего школьного возраста (n=20), II - девушки старшего школьного возраста $(\mathrm{n}=20)$. Регистрацию кардиоинтервалограмм осуществляли, используя комплекс «КардиоЛаб». Запись ВСР проводили в экспериментальных ситуациях: фоновая проба, запись ВСР во время выполнения когнитивного задания. Временные показатели $\mathrm{mRR}, \mathrm{SDNN}$, pNN50, CV, Mo, AMо характеризовались высшими значениями у девушек-старшеклассниц, по сравнению с испытуемыми среднего школьного возраста, а показатель ИН(SI) - у девочек среднего школьного возраста, по сравнению с старшеклассницами. Временные характеристики $\mathrm{mRR}$, SDNN, pNN50, CV, Мо во время решения когнитивных заданий, по сравнению с фоном, характеризовались более низкими значениями независимо от возраста. АMo, $\mathrm{IH}(\mathrm{SI})$ характеризовались увеличением их значений во время решения математических примеров, по сравнению с фоновой записью ВСР. У лиц среднего школьного возраста решение когнитивных заданий сопровождалось большим психоэмоциональным напряжением организма, компенсаторным дисстрессом и преобладанием симпатического уровня регуляции в сердечной деятельности.

Ключевые слова: вариативность сердечного ритма, дисстресс, ваготония, симпатикотония.

Kachynska Tetiana, Abramchuk Olga, Polischuk Oksana, Shershen Yulia. Time Analysis of Heart rate Variability of Female Different Years During Fulfillment of the Cognitive Tasks. The purpose of the work was to study the timing performances of heart rate variability of female different years during fulfillment of the cognitive tasks. The research was conducted on 40 females, $12-13$ and 15-17 years old, divided into groups: I-females-teenagers $(\mathrm{n}=20)$, II-females-adult $(\mathrm{n}=20)$. The cardiointervalogram was registered with the usage of computer cardiographic complex «KardioLab». The recording of HRV was conducted in experimental situations: background test, recording of HRV during fulfillment of the cognitive tasks. Timing figures: mRR, SDNN, pNN50, CV, Mo, AMo characterized by higher values in girls-adult, compared with teenagersfemales, SI - the females-teenagers, compared the females-adult. Time characteristics mRR, SDNN, pNN50, CV, Mo in the solution of cognitive tasks compared to the background, characterized by lower values, regardless of age. AMo, IH (SI) were characterized by increase their value while solving mathematical examples, compared with background recording of HRV. At 
the teenagers cognitive tasks decision accompanied by a large psycho-emotional stress of the body, and the predominance of compensatory distress level of sympathetic regulation of cardiac activity.

Key words: heart rate variability, distress, vagotonia, sympathicotonia.

Стаття надійшла до редколегії 24.11.2015 p.

УдК 57.047:616.018[612.32]

\author{
Валентина Луженецька, \\ Галина Кузнєцова, \\ Ганна Світіна, \\ Людмила Гарманчук, \\ Володимир Шаблій, \\ Володимир Рибальченко
}

\title{
Вплив плацентарних клітин мезенхімального походження на слизову оболонку шлунка щурів
}

Досліджено вплив плацентарних мезенхімальних клітин алогенного та ксеногенного походження на слизову оболонку фундального відділу шлунка щурів. Показано, що мезенхімальні стовбурові клітини щурів і людини мають негативний вплив на слизову оболонку шлунка, що прямо пропорційний кількості уведення клітин.

Ключові слова: клітинна терапія, мезенхімальні стовбурові клітини, стовбурові клітини щурів, стовбурові клітини людини, слизова оболонка шлунка.

Постановка наукової проблеми та її значення. Клітинна терапія - сучасний метод лікування захворювань, що потребують масивного відновлення тканин, в основі якого лежить трансплантація від донора до реціпієнта стовбурових і прогеніторних клітин (алотрансплантація) або власних клітин (аутотрансплантація). Стовбурові клітини (СК) успішно використовують у терапії опіків та ран, гострого інфаркту міокарда, для відновлення кровотворної активності червоного кістового мозку після хіміотерапії чи при імунодефіцитах [1]. Наявні відомості про застосування СК у терапії нейродегенеративних [2] й аутоімунологічних захворювань [3].

Найбільш перспективними в плані клінічного застосування виявилися мезенхімальні стовбурові клітини (МСК) - плюрипотентні стовбурові клітини дорослого організму, що забезпечують відновлення тканин хазяїна, здатні диференціюватися в напрямі низки соматичних клітин [4]. У ролі джерел МСК використовують червоний кістковий мозок, пуповинну кров та плаценту, жирову тканину, слизову оболону носоглотки.

При захворюваннях і пошкодженнях МСК задіяні в процесах тканинної регенерації, а також беруть участь у регуляції імунної відповіді [5]. При репарації МСК мігрують у ділянку пошкодження, «приваблені» цитокінами запалення. МСК також мають здатність до хоумінгу - міграції в ділянку своєї «стовбурової ніші». Органи, у яких переважно накопичуються МСК при внутрішньовенному уведенні, - це червоний кістковий мозок, селезінка, легені, печінка, слизова оболонка шлунка [12], а також пухлинні вузли. Тому широке застосування МСК у медичній практиці неможливе без грунтовного вивчення їх онкогенного потенціалу. Так, МСК можуть бути джерелом пухлино-асоційованих фібробластів, які $є$ важливими компонентами строми пухлини й активаторами пухлинного росту [6]. За даними інших науковців [7], МСК активно мігрують до первинної пухлини або метастатичного вузла, де, впливачи на мікооточення пухлини, пригнічують іiі ріст. У дослідженнях in vitro при співкультивуванні пухлинних клітин та МСК показано різноспрямований вплив останніх на проліферацію й виживання пухлинних клітин залежно від їх природи та умов культивування [17]. Наведені дані свідчать про неоднозначність ефектів МСК і важливість грунтовного вивчення їхньої поведінки в організмі за умов норми й різних патологічних станів. При цьому особливу увагу варто звернути на органи - мішені МСК.

\footnotetext{
(С Луженецька В., Кузнєцова Г., Світіна Г., Гарманчук Л., Шаблій В., Рибальченко В., 2015
} 